\title{
COVID-19 and physical activity: What is the relation between exercise immunology and the current pandemic situation?
}

\author{
COVID-19 and physical activity: What is the relation between exercise \\ immunology and the current pandemic situation?
}

Guilherme Gomes Azizi 1,6, Marco Orsini2,3,4, Sérgio Duarte Dortas Júnior ${ }^{1,5}$, Paulo César Vieira ${ }^{2,6}$, Ricardo Steiner de Carvalho6, Cláudio Sérgio da Rocha Pires ${ }^{2,6}$, Sebastião Carlos Ferreira da Silva ${ }^{6}$, Bruno Mendes de Sá Pinto ${ }^{6,7}$, Carlos Eduardo

Cardoso ${ }^{4}$, Adalgiza Mafra Moreno², Marco Antonio Alves Azizi ${ }^{2,6}$

\begin{abstract}
1. Serviço de Imunologia, Hospital Universitário Clementino Fraga Filho (HUCFF-UFRJ), Rio de Janeiro, RJ, Brazil. 2. Universidade Iguaçu - UNIG, Nova Iguaçu, RJ, Brazil. 3. Serviço de Neurologia/Neurocirurgia Universidade Federal Fluminense - UFF, Niterói, RJ, Brazil. 4. Universidade de Vassouras - USS, Vassouras, RJ, Brazil. 5. Departamento de Clínica Médica - Universidade Federal do Rio de Janeiro - UFRJ, Rio de Janeiro, RJ, Brazil. 6. Fluminense Football Club, Rio de Janeiro, RJ, Brazil. 7. Hospital Casa de Portugal, Rio de Janeiro, RJ, Brazil.
\end{abstract}

Exercise immunology is a strong and mysterious science in sports medicine, but studies were origin more than a 100 years ago, when Schulte had already described an exercise-induced leukocytosis as early as 1893 [1]. Since then, both cross-sectional and longitudinal studies in humans have demonstrated the profound impact that exercise can have on the immune system. That is exactly why it is fundamentally important in this pandemic time to elucidate many questions and direct the athletes and non-athletes to the due care.

The current situation started with a cluster of pneumonia patients with an unidentified cause emerged in Wuhan, Hubei Province, China, in December 2019 [2]. Approximately 2 months later the World Health Organization (WHO) announced a standard format of Coronavirus Disease-2019 (COVID-19) [3] on the same day named as SARS-CoV-2 [4].

After sequence and evolutionary tree analysis, SARS-CoV-2 was considered as a member of $\beta$-CoVs $[5,6]$ like SARS coronavirus (SARS-CoV) and MERS coronavirus (MERS-CoV) [7].

Respiratory droplets and contact transmission are the main transmission routes, but SARS-CoV-2 can be detected in the urine and stool, which gets a possible risk of fecal-oral transmission [8]. However, there is still no evidence that corroborates this route, but all possible transmission routes need vigilance during the physical exercise. COVID-19 has a probable asymptomatic incubation period ( $2-14$ days) which the virus can be transmitted [9]. SARS-CoV-2 has a Ro of 2.2-2.6, everyone has the potential to spread the infection to 2.2 other people [10].

Initially, the most common symptoms were reported in 41 patients 
with fever (98\%), cough (76\%), and myalgia or fatigue (44\%) sputum production $(28 \%)$, headache $(8 \%)$, hemoptysis $(5 \%)$, and diarrhea (3\%). More than half of patients developed dyspnea Blood test showed normal or reduced (25\%) leukocytes count and lymphopenia (65\%) [11].

Another study showed 140 patients diagnosed as COVID-19, where the most common symptoms were fever (91.7\%), cough (75\%), fatigue (75\%) and chest tightness or dyspnea (36.7\%). 39.6\% of them complained gastrointestinal symptoms. $90(64.3 \%)$ patients had comorbidity, the most common of which were chronic diseases, such as hypertension (30\%) and diabetes (12.1\%). Only two COPD patients were identified, and 2 patients reported chronic urticaria. Other allergic diseases as asthma, allergic rhinitis, food allergy, atopic dermatitis were not self-reported [12].

Persons older than 60 years old with hypertension, diabetes, COPD, cardiovascular, cerebrovascular, liver, kidney, and gastrointestinal diseases are more susceptible to the infection by SARS-CoV-2 and experience higher mortality when they develop COVID-19 [13-15].

These clinical features suggested the possibility of involvement of highly pro-inflammatory condition in the disease progression and severity. This early high rise in the serum levels of pro-inflammatory cytokines were also observed in SARS-CoV and MERS-CoV infection, suggesting a potential similar cytokine storm-mediated disease severity $[16,17]$.

In severe cases of SARS-CoV or MERS-CoV infection, there is an increased neutrophil and monocyte-macrophages influx $[18,19]$. With all knowledge accumulated about previous coronavirus infections, innate immune response plays a crucial role in antiviral and against coronavirus responses.

Thereby, we need to understand immune and inflammatory conditions that involve COVID-19. A recent study of 41 hospitalized patients with high-levels of pro-inflammatory cytokines including IL-2, IL-7, IL-10, G-CSF, IP-10, MCP-1, MIP-1A, and TNF- $\alpha$ were observed in the COVID-19 severe cases [11].

Another report demonstrated increased cytokine levels (IL-6, IL-10, and TNF- $\alpha$ ), lymphopenia (in CD4+ and CD8+ T cells), and decreased IFN $-\gamma$ expression in CD4+ $\mathrm{T}$ cells are associated with severe COVID-19 [20].

Named "cytokine storm" it may have a major role in the pathogenesis of COVID-19 may to be related a downstream cytokine cascade involving IL-1, IL-6, IL-12 and TNF- $\alpha$ [21], followed by the development of lung tissue damage resulting in ARDS, sepsis, and organ failure. The risk of respiratory failure in patients with circulating IL-6 $>80 \mathrm{pg} / \mathrm{ml}$ was 22 -fold higher with a median time to mechanical ventilation of 1.5 days [22].

Recently, a histopathological study with 4 patients in pos-mortem presented a rigorous lungs examination showing a bilateral diffuse alveolar damage with a comparatively mild-to-moderate lymphocytic infiltrate, composed of a mixture of $\mathrm{CD} 4+$ and $\mathrm{CD} 8+$ lymphocytes. The dominant process in all cases was consistent with diffuse alveolar damage, with a mild to moderate mononuclear response consisting of notable CD4+ aggregates around thrombosed small vessels, and significant associated hemorrhage [23].

A rapid and well-coordinated innate immune response is the first line of defense against viral infections, but dysregulated immune responses may cause immunopathology [24-26]. The innate immune system utilizes pathogen associated molecular patterns (PAMPs) to recognize the invasion of the virus. After a long intracellular signaling cascade, transcription factors induce expression 
of type I IFN and other pro-inflammatory cytokines and respond at the first-line defense [27]. The interferon (IFN) type I is essential to the innate immune response against viral infection in association with controlling viral replication and effective adaptive immune response. However, SARS-CoV and MERS-CoV, a SARS-CoV-2 similar virus employes multiple strategies to interfere with the signaling leading to production, function or associated to type I IFN cascade [27-29].

When talking about social isolation and pandemic, there is a need to understand behavioral aspects that can influence the health of population, being exercise a factor of interest, which can have both positive and negative effects on immune function and possible susceptibility to illnesses and upper respiratory diseases.

A single bout of exercise has a profound effect on total number and composition of circulating leukocytes. After a dynamic exercise (minutes) the total leukocyte count increases two- to threefold whereas prolonged endurance exercise (30min-3h) counts for a fivefold increment. Exercise-induced leukocytosis, mainly neutrophils and lymphocytes with a smaller contribution being made from monocytes, is a transient phenomenon, with normal counts returning to pre exercise levels (6-24 h) after exercise cessation. 30-60 min after exercise cessation, a rapid lymphocytopenia [30-32] occurs concomitantly with a sustained neutrophilia $[30,33]$.

Acute exercise causes substantial increases in hemodynamics, which place greater mechanical forces on the endothelium, thereby the leukocytes to demarginate and enter the free-flowing circulation, in association there are more levels of shear stress within the capillary structures, driving more leukocytes into the peripheral circulation.

Physical activity results in the secretion of catecholamines and corticotropin releasing hormone and cortisol, which are importantly responsible for the mobilization of monocyte during exercise, lymphocyte within minutes of engaging in dynamic exercise and neutrophil that continue their increase, often reaching peak values within a few hours after exercise cessation [34,35].

Many studies demonstrated an important innate cells response to acute moderate-intensity exercise, for example, it enhances neutrophil chemotaxis [36], as phagocytosis is enhanced immediately after a single exercise bout [37], but neutrophil degranulation in response to bacterial stimulation appears to be impaired [38]. After moderate intensity exercise the neutrophil oxidative burst continues to be enhanced, however, this is not true after exhaustive or prolonged exercise [38,39], other findings are related to well-trained athletes that are sensitive to the increases of training load, what present loss-making alterations in the neutrophil-monocyte oxidative burst, $\mathrm{CD} 4 / \mathrm{CD} 8$ ratios, lymphocyte proliferation, antibody synthesis, and NK-cell cytotoxic activity [41-45]. What can occur during 1-3 weeks of intensified training, generating reductions in neutrophil function, lymphocyte proliferation and mucosal IgA $[42,43,46]$.

Immunoglobulin A (IgA) is an important part of the mucosal immune system. There is not a consensus on the impact of acute exercise on salivary IgA (sIgA), because many factors may influence the response like a training status, intensity and duration of the exercise bout, saliva collection, nutrition [30].

The inverse relationship between sIgA concentrations and risk of airway infections in exercising and non-exercising populations has demonstrated differences between these two populations [46-48]. The impact of exercise 
intensity on sIgA concentrations and secretion rates has demonstrated greater decreases in sIgA associated with prolonged high intensity exercise, whereas moderate increases in sIgA occur in response to short duration moderate intensity exercise [48-51].

A study monitored the stress-induced alteration in concentrations of sIgA and cortisol, and the incidence of upper respiratory tract infections over the course of a 9-week season in college. 14 student-athletes and 14 college students, all being young and women, demonstrate decreased levels of sigA and increase in the indices of training (load, strain, and monotony) were associated with an increase in the incidence of illness during the 9-week competitive soccer season [52].

The "open window" hypothesis is an important idea that explains when an endurance athlete repeats bouts of acute strenuous exercise without adequate recovery why opportunistic infections may enjoy this till $72 \mathrm{~h}$ after the exercise [53]. Although exercise immunology researchers discuss the "open window" and if it is the only real association between upper respiratory infections or symptoms and the strenuous exercise, a large body of evidence supports the proposition that elite athletes undertaking prolonged heavy intensive exercise can exhibit immune changes, in association with physiological, metabolic, and psychological stressors, and pathogen/allergen exposure, that increase the risk of infection and/or airway inflammation [54].

Otherwise, regular moderate-intensity exercise has been linked a to better vaccine responses [55,56], lower numbers of exhausted T-cells [57], increased T-cell proliferation [58] lower levels of circulating inflammatory cytokines [59], increased neutrophil phagocytic activity [60], greater NK-cell cytotoxic activity [61], indicating that regular moderate-intensity exercise is capable of improving, or maintaining, immunity across the life [62]. In addition, may help prolong or reinvigorate thymic activity, which we can observe with increased plasma levels of IL-7 [63].

Concurrently, subtle elevations in stress hormones released from skeletal muscle, notably interleukin-6 (IL-6), is observed during acute bouts of moderate-intensity exercise; however, the pleiotropic nature of IL-6 appears to provide protection (versus harm) to immunity via directly suppressing potent inflammatory cytokines [e.g., tumor necrosis factor alpha (TNF-a)] in the lungs, creating an anti-inflammatory milieu for several hours post-exercise [64].

The literature presents many studies about competitions that demonstrates the profile between athlete high-level moment and illness. In the Rio Olympic Games, in a total, 11274 athletes (5089 women, 45\%; 6185 men, 55\%) was reported for Rio 2016 medical staff 651 illnesses over the 17-day period (47\% affected the respiratory and $21 \%$ the gastrointestinal systems) [65].

In the 2010 Fifa World Cup Ninety-nine illnesses were reported in 89 players $(12.1 \%$ of all players). Most illnesses affected either the respiratory $(40 ; 40.4 \%)$ or the digestive $(26 ; 26.3 \%)$ system. The most frequent diagnoses were acute upper respiratory tract infection $(31 ; 31.3 \%)$ and gastroenteritis (21; $21.2 \%)[66]$.

Another factor is the carbohydrate availability, which an essential component to the immune performance, because to perform in a state of glycogen depletion there is an increased catecholamine and glucocorticoid, creating a greater decline of the T-cell, NK-cell, and neutrophil and depressed immune function compared to exercise on a normal or high carbohydrate diet $[67,68]$. 
Therefore, the previous extensive medicine and immunological knowledge provide us with the understanding that the increased incidence of infection in athletes is multifactorial maybe physical, psychological, environmental or nutritional what suppress the immune system [69]. In addition, a variety of causes can be an association with airway symptoms and could include physical damage such as drying of the airways [70], asthma and allergic airway inflammation [71] and psychological impacts of exercise on membrane integrity [72].

Special considerations regarding exercise and immune health must be addressed for older adults who represent the growing population globally, and incidentally are the most sensitive to developing infectious disease. Immunosenescence described as the phenomenon responsible for the inextricable deterioration of immune competency that occurs with increasing age, is believed to be the primary factor explaining the lowered immune vigilance, poorer responses to vaccinations and the greater risk, and morbidity, associated with infectious diseases, including COVID-19 outbreak. Given the already described beneficial effects of habitual moderate-intensity exercise on aspects of immunity in younger populations, physical activity is suggested to be a logical therapeutic strategy to abate aging effect son the immune system. It is well supported by a growing body of evidence from epidemiological and experimental studies in older adults indicating that regular participation in moderate-intensity exercise attenuates age-related oxidative stress and reduces the frequency of various immune biomarkers that are associated with compromised immunity, thereby suggesting that exercise may delay the onset of immunosenescence and attenuate the risk of infection [73].

\section{Suggestions}

In consideration of the knowledge previously explained and possible association to doubt moment and SARS-CoV-2 risk contagion, this research group proposed some suggestions from athletes and non-athletes during the COVID-19 pandemic, looking up a health manutention and good conditions to a future return to the competitions. Thereby, avoid SARS-CoV-2 infection and/ or severe complications.

1- We considered that this moment is not adequate to a high level of training/extreme physical effort. Preserve your regular physical activity and moderate intensity, avoiding greater risks of contamination and detraining. You must know that for each week of total inactivity, you can loss of up to $10 \%$ of fitness [64].

2- Measures to reduce or stop smoking has fundamental importance. Approximately six million people worldwide die due to tobacco use each year [74]. The cigarette contributes to the pathogenesis and a recognized risk factor of chronic obstructive pulmonary disease (COPD), hypertension, cardiovascular disease, cancer, chronic systemic diseases with inflammatory components such as atherosclerosis, and type 2 diabetes mellitus $[75,76]$. Smokers are vulnerable to respiratory viruses and the tobacco upregulates the angiotensin-converting enzyme-2 (ACE2) receptor compared to non-smokers, irrespective of tissue subset or COPD 
status, increasing pulmonary ACE2 expression by 25\%, which is the receptor for both the severe acute respiratory syndrome (SARS)-coronavirus SARS-CoV and SARS-CoV-2. Thereby, smokers can be more susceptible to the development of COVID-19 [77,78].

3- Avoid changes in your treatment for chronic diseases, pulmonary or not, without the advice of your physiciam.

4- Avoid medications and formulas without a scientific basis for prevention and treatment to COVID-19 infection.

5- Avoid alcohol ingest and maintain your sleep quality.

6- Aerobic or resistance activities in safe environments and respecting the adequate social distance. Preferably, in covered and closed places that can be thoroughly cleaned after the activity and following the recommendations of the competent local authorities. It is so necessary because droplets travel a distance 1.8 meters in the air and the average life of COVID-19 is 2.7 hours in the air and 13 hours on steel [77].

7- Maintain the hygiene of your sports equipment.

8- Make an adequate ingest of proteins and carbohydrates, always consulting your support professional, prioritizing a multidisciplinary work between nutritionists, doctors, physical educators, in addition to your mental health, and those around you, seek assistance from your sports psychologist and other competent professionals for your health.

9- We do not recommend training in case of fever in a COVID infection or others suggest symptoms.

10- Exercise at home using various safe, simple, and easily implementable exercises is well suited to avoid the airborne coronavirus and maintain fitness levels. Examples of home exercises include walking in the house, lifting and carrying food bags, alternating leg, stair climbing, stand-to-sit and sit-to-stand using a chair and from the floor, and sit-ups and pushups [78-80].

\section{Conclusion}

In conclusion, regular exercise training of moderate intensity is believed to exert beneficial effects on immune function and must be associated to the suggestions.

We sought to clarify the importance of the regular exercise of a moderate intensity and the likely risks evolvement to inadequate exercise associated with poor diet and habits, and physiological alteration. In this way, we advise moderation, tranquility, and patience in this pandemic period. 


\section{References}

1. Shephard RJ. The history of exercise immunology. In: Tipton C, ed. The history of exercise physiology. Champaign, IL: Human Kinetics; 2010

2. Li Q, Guan X, Wu P, Wang X, Zhou L, Tong Y, Ren R, Leung KSM, Lau EHY, Wong JY et al. Early transmission dynamics in Wuhan, China, of novel coronavirus-infected pneumonia. N Engl J Med 2020;382(13):1199-207 https://doi.org/10.1056/nejmoa2001316

3. World Health Organization Press Conference. The World Health Organization (WHO) has officially named the disease caused by the novel coronavirus as COVID-19. https://www.who. int/emergencies/diseases/novel-coronavirus-2019/events-as-they-happen

4. Gorbalenya AE, Baker SC, Baric RS, de Groot RJ, Drosten C, Gulyaeva AA, Haagmans BL, Lauber $\mathrm{C}$, Leontovich AM, Neuman BW et al. Severe acute respiratory syndrome-related coronavirus: The species and its viruses-A statement of the Coronavirus Study Group. Nature Microbiology https://doi.org/10.1038/s41564-020-0695-Z

5. Zhu N, Zhang D, Wang W, Li X, Yang B, Song J, Zhao X, Huang B, Shi W, Lu R et al. A novel coronavirus from patients with pneumonia in China, 2019. N Engl J Med 2020;382(8):727-33. https://doi.org/10.1056/nejmoa2001017

6. Zhou P, Yang XL, Wang XG, Hu B, Zhang L, Zhang W, Si HR, Zhu Y, Li B, Huang CL et al. A pneumonia outbreak associated with a new coronavirus of probable bat origin. Nature 2020;579(7798):270-3. https://doi.org/10.1038/s41586-020-2012-7

7. Weiss SR, Leibowitz JL. Coronavirus pathogenesis. Advance in virus research; 2011. p.85-164. https://doi.org/10.1016/b978-0-12-385885-6.00009-2

8. General Office of National Health Commission; General Office of National Administration of Traditional Chinese Medicine. Diagnostic and treatment protocol for Novel Coronavirus Pneumonia. https://www.chinadaily.com.cn/pdf/2020/1.Clinical.Protocols.for.the.Diagnosis. and.Treatment.of.COVID-19.V7.pdf

9. Center for Disease Control and Prevention. Atlanta: CDC. Symptoms of Novel Coronavirus (2019-nCoV). 2020 https://www.cdc.gov/coronavirus/2019-ncov/

10. Wu F, Zhao S, Yu B, Chen YM, Wang W, Song ZG et al. A new coronavirus associated with human respiratory disease in China. Nature 2020;580(7803):E7. https://doi.org/10.1038/s41586020-2202-3

11. Huang C, Wang Y, Li X, Ren L, Zhao J, Hu Y, Zhang L, Fan G, Xu J, Gu X et al. Clinical features of patients infected with 2019 novel coronavirus in Wuhan, China. Lancet 2020;395(10223):497-506. https://doi.org/10.1016/s0140-6736(20)30183-5

12. Zhang JJ, Dong X, Cao YY, Yuan YD, Yang YB, Yan YQ, Akdis CA, D. Clinical characteristics of 140 patients infected with SARS-CoV-2 in Wuhan, China. Allergy 27/02/2020. https://doi. org/10.1111/all.14238

13. Arentz M, Yim E, Klaff L, Lokhandwala S, Riedo FX, Chong M, Lee M. Characteristics and outcomes of 21 critically Ill patients with COVID-19 in Washington State. JAMA 2020;323(16):1612. https://doi.org/10.1001/jama.2020.4326.

14. Team TNCPERE. The epidemiological characteristics of an outbreak of 2019 novel coronavirus diseases (COVID-19) - China, 2020. China CDC Weekly 2020;2:113-22.

15. Zhou F, Yu T, Du R, Fan G, Liu Y, Liu Z, Xiang J, Wang Y, Song B, Gu X, Guan L, Wei Y, Li H, Wu X, $\mathrm{Xu}$ J, Tu S, Zhang Y, Chen $\mathrm{H}$, Cao B. Clinical course and risk factors for mortality of adult inpatients with COVID-19 in Wuhan, China: a retrospective cohort study. Lancet 2020;395(10229):1054-62. https://doi.org/10.1016/S0140-6736(1020)30566-30563.

16. Mahallawi WH, Khabour OF, Zhang Q, Makhdoum HM, Suliman BA. MERS-CoV infection in humans is associated with a pro-inflammatory Th1 and Th17 cytokine profile. Cytokine 2018;104:8-13. https://doi.org/10.1016/j.cyto.2018.01.025

17. Wong CK, Lam CW, Wu AK, Ip WK, Lee NL, Chan IH et al. Plasma inflammatory cytokines and chemokines in severe acute respiratory syndrome. Clin Exp Immunol 2004;136(1):95-103. doi. org/10.1111/j.1365-2249.2004.02415.x

18. Perlman S, Dandekar AA. Immunopathogenesis of coronavirus infections: implications for SARS. Nat Rev Immunol 2005;5(12):917-27. https://doi.org/10.1038/nri1732 
19. Zumla A, Hui DS, Perlman S. Middle East respiratory syndrome. Lancet 2015;386(9997):9951007. https://doi.org/10.1016/s0140-6736(15)60454-8

20. Pedersen SF, Ho YC. SARS-CoV-2: a storm is raging. J Clin Invest 2020;130(5):2202-5. https:// doi.org/10.1172/jci137647

21. Mehta P, McAuley DF, Brown M, Sanchez E, Tattersall RS, Manson JJ et al. COVID-19: consider cytokine storm syndromes and immunosuppression. Lancet 2020;395(10229):1033-4.. https:// doi.org/10.1016/s0140-6736(20)30628-0

22. Herold TVJ, Arnreich C, Hellmuth JC, von Bergwelt-Baildon M, Klein M, Weinberger T. Level of IL-6 predicts respiratory failure in hospitalized symptomatic COVID-19 patients. medRxiv 2020 https://doi.org/10.1101/2020.04.01.20047381

23. Fox SE, Akmatbekov A, JHarbert JL, Li G, 3Brown JQ, Vander Heide RS. Pulmonary and cardiac pathology in Covid-19: the first autopsy series from New Orleans. medRxiv 2020. https:// doi.org/10.1101/2020.04.06.2005057

24. Channappanavar R et al. Dysregulated type I interferon and inflammatory monocyte-macrophage responses cause lethal pneumonia in SARS-CoV-infected mice. Cell Host Microbe 2016;19(2):181-93. https://doi.org/10.1016/j.chom.2016.01.007

25. Davidson S et al. Disease-promoting effects of type I interferons in viral, bacterial and coinfections. J Interf Cytokine Res 2015;35(4):252-64. https://doi.org/10.1089/jir.2014.0227

26. Shaw AC et al. Age-dependent dysregulation of innate immunity. Nat Rev Immunol 2013;13(12):875-87. https://doi.org/10.1038/nri3547

27. de Wit E, van Doremalen N, Falzarano D, Munster VJ. SARS and MERS: recent insights into emerging coronaviruses. Nat Rev Microbiol 2016;14(8):523-34. https://doi.org/10.1038/nrmicro.2016.81

28. Channappanavar R, Perlman S. Pathogenic human coronavirus infections: causes and consequences of cytokine storm and immunopathology. Semin Immunopathol 2017;39(5):529-39. https://doi.org/10.1007/s00281-017-0629-X

29. Kindler E, Thiel V, Weber F. Interaction of SARS and MERS coronaviruses with the antiviral interferon response. Coronaviruses 2016. p.219-43. https://doi.org/10.1016/bs.aivir.2016.08.006

30. Walsh NP, Gleeson M, Shephard RJ et al. Position statement. Part one: immune function and exercise. Exerc Immunol Rev 2011;17:6-63. https://www.ncbi.nlm.nih.gov/pubmed/21446352

31. Campbell JP, Riddell NE, Burns VE et al. Acute exercise mobilises CD8+ T lymphocytes exhibiting an effector-memory phenotype. Brain Behav Immun 2009;23(6):767-75. https://doi.org/10.1016/j.bbi.2009.02.011

32. Simpson RJ, Florida-James GD, Whyte GP, Black JR, Ross JA, Guy K. Apoptosis does not contribute to the blood lymphocytopenia observed after intensive and downhill treadmill running in humans. Res Sports Med 2007;15(3):157-74. https://doi.org/10.1080/15438620701405339

33. Simpson RJ. The effects of exercise on blood leukocyte numbers. In: Gleeson M, Bishop NC, Walsh NP, eds. Exercise Immunology. Oxford, UK, New York, USA: Routledge; 2013. p.64-105. https://doi.org/10.4324/9780203126417

34. Okutsu M, Suzuki K, Ishijima T, Peake J, Higuchi M. The effects of acute exerciseinduced cortisol on CCR2 expression on human monocytes. Brain Behav Immun 2008;22(7):1066-71. https:// doi.org/10.1016/j.bbi.2008.03.006

35. Okutsu M, Ishii K, Niu KJ, Nagatomi R. Cortisol-induced CXCR4 augmentation mobilizes Tlymphocytes after acute physical stress. Am J Physiol Regul Integr Comp Physiol 2005;288(3):R591R599. https://doi.org/10.1152/ajpregu.00438.2004

36. Ortega E, Collazos ME, Maynar M, Barriga C, De la Fuente M. Stimulation of the phagocytic function of neutrophils in sedentary men after acute moderate exercise. Eur J Appl Physiol Occup Physiol 1993;66(1):60-4. https://doi.org/10.1007/bf00863401

37. Nieman DC, Nehlsen-Cannarella SL, Fagoaga OR et al. Effects of mode and carbohydrate on the granulocyte and monocyte response to intensive, prolonged exercise. J Appl Physiol 1998;84(4):1252-9. https://doi.org/10.1152/jappl.1998.84.4.1252

38. Bishop NC, Gleeson M, Nicholas CW, Ali A. Influence of carbohydrate supplementation on plasma cytokine and neutrophil degranulation responses to high intensity intermittent exercise. Int J Sport Nutr Exerc Metab 2002;12(2):145-56. https://doi.org/10.1123/ijsnem.12.2.145

39. Pyne DB. Regulation of neutrophil function during exercise. Sports Med 1994;17(4):245-58. 
https://doi.org/10.2165/00007256-199417040-00005

40. Suzuki K, Nakaji S, Yamada $M$ et al. Impact of a competitive marathon race on systemic cytokine and neutrophil responses. Med Sci Sports Exerc 2003;35(2):348-55. https://doi. org/10.1249/01.mss.0000048861.57899.04

41. Gleeson M, McDonald WA, Cripps AW, Pyne DB, Clancy RL, Fricker PA. The effect on immunity of long-term intensive training in elite swimmers. Clin Exp Immunol 1995;102:210-6. https:// doi.org/10.1111/j.1365-2249.1995.tb06658.X

42. Lancaster GI, Halson SL, Khan Q, Drysdale P, Jeukendrup AE, Drayson MT, Gleeson M. Effect of acute exhaustive exercise and a 6-day period of intensified training on immune function in cyclists. J Physiol 2003;548P:O96. https://www.physoc.org/abstracts/effect-of-acute-exhaustive-exercise-and-a-6-day-period-of-intensified-training-on-immune-function-in-cyclists/

43. Lancaster GI, Halson SL, Khan Q, Drysdale P, Jeukendrup AE, Drayson MT, Gleeson M. The effects of acute exhaustive exercise and intensified training on type 1/type $2 \mathrm{~T}$ cell distribution and cytokine production. Exerc Immunol Rev 2004;10:91-106. https://www.ncbi.nlm.nih.gov/ pubmed/15633589

44. Robson PJ, Blannin AK, Walsh NP, Bishop NC, Gleeson M. The effect of an acute period of intense interval training on human neutrophil function and plasma glutamine in endurance-trained male runners. J Physiol 1999;515:84-5.

45. Verde TJ, Thomas SG, Moore RW, Shek P, Shephard RJ. Immune responses and increased training of the elite athlete. J Appl Physiol 1992;73:1494-9. https://doi.org/10.1152/jappl.1992.73.4.1494

46. Gleeson M. Mucosal immune responses and risk of respiratory illness in elite athletes. Exerc Immunol Rev 2000;6:5-42.

47. Francis JL, Gleeson M, Pyne DB, Callister R and Clancy RL. Variation of salivary immunoglobulins in exercising and sedentary populations. Med Sci Sports Exerc 2005;37:571-8. https://doi. org/10.1249/01.mss.0000158191.08331.04

48. Gleeson M, Pyne DB and Callister R. The missing links in exercise effects on mucosal immunity. Exerc Immunol Rev 2004;10:107-28.

49. Allgrove JE, Gomes E, Hough J and Gleeson M. Effects of exercise intensity on salivary antimicrobial proteins and markers of stress in active men. J Sports Sci 2008;26:653-61. https://doi. org $/ 10.1080 / 02640410701716790$

50. Bishop NC and Gleeson M. Acute and chronic effects of exercise on markers of mucosal immunity. Front Biosci 2009;14:4444-56.

51. Klentrou P, Cieslak T, MacNeil M, Vintinner A and Plyley M. Effect of moderate exercise on salivary immunoglobulin A and infection risk in humans. Eur J Appl Physiol 2002;87:153-8. https://doi.org/10.1007/s00421-002-0609-1

52. Putlur P, Foster C, Miskowski JA, Kane MK, SBurton SE, Scheett TP, McGuigan MR. Alteration of immune function in women collegiate soccer players and college students. J Sports Sci Med 2004;3;234-43. https://www.ncbi.nlm.nih.gov/pmc/articles/PMC3938062/

53. Pedersen BK, Ullum $\mathrm{H}$. NK cell response to physical activity: possible mechanisms of action. Med Sci Sports Exerc 1994;26(2):140-6. https://doi.org/10.1249/00005768-199402000-00003

54. Simpson RJ, Campbell JP, Gleeson $M$ et al. Can exercise affect immune function to increase susceptibility to infection? Exerc Immunol Rev 2020;26:8-22. http://eir-isei.de/2020/eir-2020-008-article.pdf

55. Kohut ML, Arntson BA, Lee W et al. Moderate exercise improves antibody response to influenza immunization in older adults. Vaccine 2004;22(17/18):2298-306. https://doi.org/10.1016/j. vaccine.2003.11.023

56. Woods JA, Keylock KT, Lowder $\mathrm{T}$ et al. Cardiovascular exercise training extends influenza vaccine seroprotection in sedentary older adults: the immune function intervention trial. J Am Geriatr Soc 2009;57(12):2183-91. https://doi.org/10.1111/j.1532-5415.2009.02563.X

57. Spielmann G, McFarlin BK, O'Connor DP, Smith PJ, Pircher H, Simpson RJ. Aerobic fitness is associated with lower proportions of senescent blood T-cells in man. Brain Behav Immun 2011;25(8):1521-9. https://doi.org/10.1016/j.bbi.2011.07.226

58. Shinkai S, Kohno H, Kimura K et al. Physical activity and immune senescence in men. Med Sci Sports Exerc 1995;27(11):1516-26. https://doi.org/10.1249/00005768-199511000-00008 
59. Pedersen BK, Bruunsgaard $\mathrm{H}$. Possible beneficial role of exercise in modulating lowgrade inflammation in the elderly. Scand J Med Sci Sports 2003;13(1):56-62. https://doi.org/10.1034/ j.1600-0838.2003.20218.x

60. Yan H, Kuroiwa A, Tanaka H, Shindo M, Kiyonaga A, Nagayama A. Effect of moderate exercise on immune senescence in men. Eur J Appl Physiol 2001;86(2):105-11. https://doi.org/10.1007/ s004210100521

61. Woods JA, Ceddia MA, Wolters BW, Evans JK, Lu Q, McAuley E. Effects of 6 months of moderate aerobic exercise training on immune function in the elderly. Mech Ageing Dev 1999;109(1):119. https://doi.org/10.1016/s0047-6374(99)00014-7

62. Simpson RJ, Lowder TW, Spielmann G, Bigley AB, Lavoy EC, Kunz H. Exercise and the aging immune system. Ageing Res Rev 2012;11:404-20. https://doi.org/10.1016/j.arr.2012.03.003

63. ElKassar N, Gress RE. An overview of IL-7 biology and its use in immunotherapy. J Immunotoxicol 2010;7(1):1-7. https://doi.org/10.3109/15476910903453296

64. Laddu DR, Lavie CJ, Phillips SA, Arena R. Physical activity for immunity protection: Inoculating populations with healthy living medicine in preparation for the next pandemic [published ahead of print, 2020 Apr 9]. Prog Cardiovasc Dis 2020. https://doi.org/10.1016/j.pcad.2020.04.006 65. Soligard T, Steffen K, Palmer D, et al. Sports injury and illness incidence in the Rio de Janeiro 2016 Olympic Summer Games: A prospective study of 11274 athletes from 207 countries. Br J Sports Med 2017;51(17):1265-71. https://doi.org/10.1136/bjsports-2017-097956

66. Dvorak J, Junge A, Derman W, Schwellnus M. Injuries and illnesses of football players during the 2010 FIFA World Cup. Br J Sports Med 2011;45(8):626-30. https://doi.org/10.1136/ bjsm.2010.079905

67. Davison G, Simpson RJ. Immunity. In: Lanham-New SA, Stear SJ, Shirreffs SM, Collins AL, eds. Sport and exercise nutrition. Oxford, UK: Wiley-Blackwell; 2011. p.281-303.

68. Walsh NP, Gleeson M, Pyne DB et al. Position statement. Part two: maintaining immune health. Exerc Immunol Rev 2011;17:64-103.

69. Gleeson M, ed. Immune function in sport and exercise. Edinburgh: Elsevier; 2005.

70. Bermon S. Airway inflammation and upper respiratory tract infection in athletes: is there a link? Exerc Immunol Rev 2007;13:6-14.

71. Helenius I, Lumme A, Haahtela T. Asthma, airway inflammation and treatment in elite athletes. Sports Med 2005;35:565-574. ttps://doi.org/10.2165/00007256-200535070-00002

72. Bjermer L, Anderson SD. Bronchial hyperresponsiveness in athletes: mechanisms for development. Eur Respir Mon 2005;33:19-34. https://doi.org/10.1183/1025448x.00033004

73. Varandas F, Medina D, Gomez A, Della Villa S. Late rehabilitation on the field. In: Injury and health problem in football. Berlin Heidelberg: Springer; 2017. p.571-9.

74. World Health Organization. Global report on trends in prevalence of tobacco smoking. Geneva, Switzerland: WHO; 2015.

75. Sopori M. Effects of cigarette smoke on the immune system. Nat Rev Immunol 2002;2:372-7. https://doi.org/10.1038/nriso3

76. Stampfli MR, Anderson GP. How cigarette smoke skews immune responses to promote infection, lung disease and cancer. Nat Rev Immunol 2009;9:377-84. https://doi.org/10.1038/nri2530

77. Brake SJ, Barnsley K, Lu W, McAlinden KD, Eapen MS, Sohal SS. smoking upregulates angiotensin-converting enzyme-2 receptor: a potential adhesion site for novel coronavirus SARS-CoV-2 (Covid-19). J Clin Med 2020;9(3):841. https://doi.org/10.3390/jcm9030841

78. Cai G, Bossé Y, Xiao F, Kheradmand F, Amos CI. Tobacco smoking increases the lung gene expression of ACE2, the receptor of SARS-CoV-2 [published online ahead of print, 2020 Apr 24]. Am J Respir Crit Care Med 2020. https://doi.org/10.1164/rccm.202003-0693LE

79. Kampf G, Todt D, Pfaender S, Steinmann E. Persistence of coronaviruses on inanimate surfaces and their inactivation with biocidal agents. J Hosp Infect 2020;104(3):246-51. https://doi. org/10.1016/j.jhin.2020.01.022

80. Chen P, Mao L, Nassis GP, Harmer P, Ainsworth BE, Li F. Coronavirus disease (COVID-19): The need to maintain regular physical activity while taking precautions. J Sport Health Sci 2020;9(2):103-4. https://doi.org/10.1016/j.jshs.2020.02.001 